\title{
Optimum Form of Hydrogen Bond in Water-Alcohol Systems : A Study Through Molecular Dynamic Modelling
}

\author{
Budiono $^{1,2}$, Rani Nawang Sari ${ }^{1,3^{*}}$, Seni Metasari ${ }^{1}$ \\ *e-mail: raniradyta@gmail.com \\ ${ }^{1}$ Program Studi Kimia, Pascasarjana Universitas Sriwijaya \\ ${ }^{2}$ SMA Negeri 3 Kayu Agung, Ogan Komering Ilir, Sumatera Selatan \\ ${ }^{3}$ SMA Negeri 2 OKU, Sumatera Selatan
}

\begin{abstract}
Because of the limited human sight to the molecular view, there are still a little information gained from molecular properties especially on how its iteract. Many research equipment brought up in order to gain more information, but still it was limited. Most of nowaday equipments are works by measuring energy gained or released by molecules without view actual molecule of a compound. One best way to describe how molecules interact is using visualization that generate molecular modelling. It work by mathematics computational that measure every aspect of physical works. Of course its not a single solution, but for now its the best choice to be used. In this molecular modelling, equipment we need is the program Hyperchem (software) and computer (hardware). Main purpose is study the hydrogen bonds in water-water, methanol-water and ethanol-water system. Properties we study is stable state of hydrogen bond based on the lowest energy measured if radius, bond angle and torsion were controlled. The result showed that the most stable state of hydrogen bond in water-water system is $3,025 \AA$ in lenght, $79^{\circ}$ in $\mathrm{HO}-\mathrm{H}$ angle and $0^{0}$ in bond torsion. Meanwhile in methanol-water system is $2,935 \AA$ in lenght, $154^{\circ}$ in HO$\mathrm{H}$ angle and $257^{\circ}$ in bond torsion. For ethanol-water system the optimum form is $2,94 \AA$ in lenght, $143,5^{\circ}$ in $\mathrm{HO}-\mathrm{H}$ angle and $314^{\circ}$ in bond torsion.
\end{abstract}

Keywords : hydrogen, bond, molecule, torsion, energy

\begin{abstract}
ABSTRAK
Pengamatan terhadap model molekul masih terbatas, sedikit informasi diperoleh dari sifatsifat molekul dan interaksinya. Banyak penelitian dikembangkan untuk mendapatkan informasi tentang ini tetapi masih terbatas. Saat ini sebagian besar penelitian mengukur energi yang diperoleh atau dilepas oleh mlekul tanpa melihat solekul sebenarnya dari suatu senyawa. Salah satu cara terbaik untuk menggambarkan bagaimana molekul berinteraksi menggunakan visualisasi yang menghasilkan pemodelan molekuler. Cara ini bekerja dengan perhitungan matematika yang mengukur setiap aspek perubahan fisik. Hal ini bukan satu-satunya cara tetapi saat ini menjadi pilihan terbaik. Dalam pemodelan molekuler ini, peralatan yang kita butuhkan adalah program Hyperchem (perangkat lunak) dan komputer (hardware). Tujuan utama adalah mempelajari ikatan hidrogen dalam sistem air-air, metanol-air dan etanol. Permasalahan yang kami pelajari adalah keadaan stabil ikatan hidrogen berdasarkan energi terendah yang diukur jika jarak, sudut ikatan dan torsi dikontrol. Hasilnya menunjukkan bahwa ikatan hidrogen yang paling stabil dalam sistem air-air adalah jarak ikatan 3,025 $\AA$, sudut H-O-H $79^{\circ}$ dan torsi dalam ikatan $0^{\circ}$. Sementara itu dalam sistem metanol-air adalah jarak ikatan $2.935 \AA$ A,sudut H-O-H $154^{\circ}$ dan sudut torsi $257^{\circ}$. Untuk sistem etanol-air, bentuk optimumnya adalah jarak ikatan $2,94 \AA$, sudut H-O-H $143,5^{\circ}$ dan sudut ikatan $314^{0}$.
\end{abstract}

Kata Kunci: hydrogen, ikatan, molekul, torsi, energi 


\section{INTRODUCTION}

Nowadays, study of molecular view in scientific method still limited by the human ability. Many methods to studying molecules is based on its energy measurements. Micro-size of the molecules become main obstacle referred to human view ability. If viewing the molecule is almost impossible, so that with studying its characters and interactions. Although many equipment developed for the research, it still difficult to identificating molecular characters and interaction. Some of advanced equipments could describe the molecules and its energy, but information about its interaction is still narrow. Thus, the method to describe molecular interactions and character need to be developed further.

One of the molecular interaction that difficult to be observed is hydrogen bond. Hydrogen bond is a special type of dipole-dipole force arises between molecules that have an $\mathrm{H}$ atom bonded to a small, highly electronegative atom with lone electron pairs, specifically $\mathrm{N}, \mathrm{O}$, or F (Silberberg, 2015). In order to prove the existence of hydrogen bond, chemical quantum has its describing geometry, topology, energy and its orbitals by using method as schematic energy decomposition method, Bader's theory of atom in molecule, conceptual density functional theory, electron localization function, natural orbitals for chemical valence and so sforth (Stachowicz \& Korchowiec, 2013). But its still hard to do, moreover with limited equipping tools to research. So, the molecular simulator become right choice to determine potential energy's function from hydrogen bond (Plummer, 1990).

Molecular dynamic basically using movement function solving methods of classical mechanism integrated with computer's numeric algorithm program (Amrullah, 2016). There are so many computer's program that running molecular dynamic, such as Chimera, VMD, Chemsketch or Hyperchem. Surely every program has its own advantages and disadvantages. HyperChem is a good choice because of its ability to performs specific display of molecules conformation through computation of surface energy in two different angle (Gutowska, Machoy, \& Machaliński, 2005). By using the molecular dynamic, study about hydrogen bond can be clearly described or at least it can be a method to explain how hydrogen bond optimized in molecular interactions. It can be determined by comparising energy of molecules (bonding energy) and its properties (radius, bonding angle and torsions). The lowest energy show the most stable state of hydrogen bonds.

\section{MATERIALS AND METHOD}

Material used in this observation is mainly use Hyperchem aplication that contains water molecule modelling, methanol molecule modelling and ethanol molecule modelling. Method that used is using direct observation by manipulating bond lenght, angle and torsion $\mathrm{n}$ order to get energy generated as the result. In the end, form the results we decide the optimum form of hydrogen bond in bond lenght, angle and torsion.

\section{RESULTS AND DISCUSSION}

Hydrogen bonds in water-water, methanol-water and ethanol-water has unique character, it may comes from both sides hydrogens. Here is the hydrogen bonds in water-water, methanol-water and ethanol-water system modelling made by Hyperchem aplication based on Windows 10. 


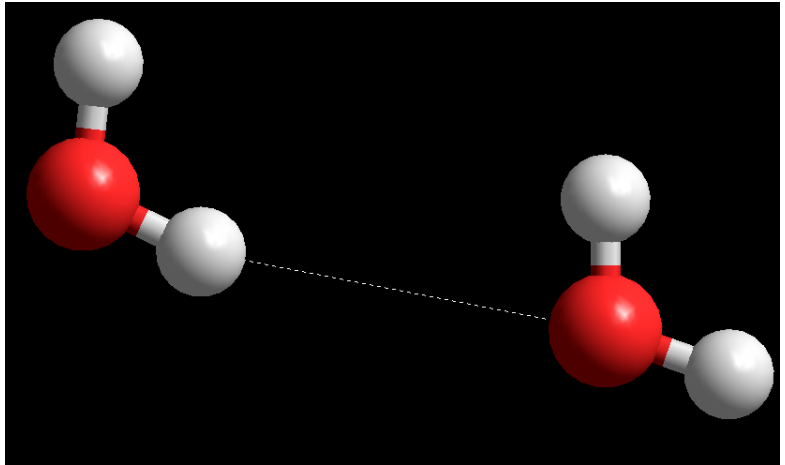

Figure 1. Molecular modelling of hydrogen bond in water-water system by using Hyperchem application.

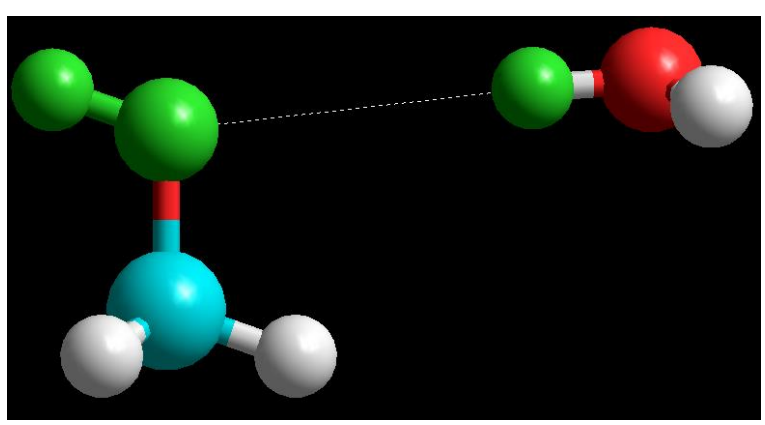

Figure 2. Molecular modelling of hydrogen bond in methanol-water system by using Hyperchem application.

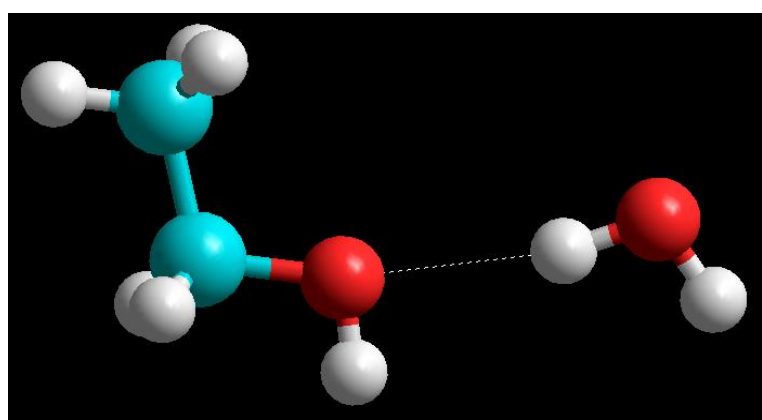

Figure 3. Molecular modelling of hydrogen bond in ethanol-water system by using Hyperchem application.

From the modelling we can see clearly the dashed line between atom $\mathrm{O}$ (red ball) and atom $\mathrm{H}$ (white-smaller ball). In the application, dashed line is the symbol of hydrogen bond. As we see, hydrogen bonding comes from atom $\mathrm{O}$ of ethanol and atom $\mathrm{H}$ from water. Wa can also make hydrogen bond from atom $\mathrm{O}$ of water and atom $\mathrm{H}$ of ethanol. Hydrogen bond has specified characters, either chemical character or physical character. Mainly, we will discuss chemical character such as bond lenght, bonding angle and bonding torsion. We will compare the three systems to get more information about hydrogen bond in the systems in case to find optimum form of hydrogen bond in the system. Using the Hyperchem we measured the energy formed when bond lenght, bond angle and bond torsion were manipulated. The lowest energy formed indicates the optimum form of hydrogen bond.

The result we measured by manipulating bond lenght and controlled bond angle-torsion is showed as following :

Table 1. The comparison of molecular energy and its radius in water-water system, methanol-water system and ethanol-water system.

\begin{tabular}{|c|c|c|c|c|c|}
\hline \multicolumn{2}{|c|}{$\begin{array}{l}\text { Water - } \\
\text { Water }\end{array}$} & \multicolumn{2}{|c|}{$\begin{array}{l}\text { Methan } \\
\text { ol - Water }\end{array}$} & \multicolumn{2}{|c|}{$\begin{array}{l}\text { Ethano } \\
\text { I - Water }\end{array}$} \\
\hline $\begin{array}{l}\text { Radius } \\
\text { (r) }\end{array}$ & $\begin{array}{c}\text { Ener } \\
\text { gy }\end{array}$ & $\begin{array}{l}\text { Radiu } \\
\text { s (r) }\end{array}$ & $\begin{array}{c}\text { Ener } \\
\text { gy }\end{array}$ & $\begin{array}{l}\text { Radiu } \\
\text { s (r) }\end{array}$ & $\begin{array}{c}\text { Ener } \\
\text { gy }\end{array}$ \\
\hline 2,990 & $\begin{array}{c}1,069 \\
654\end{array}$ & 2,800 & $\begin{array}{c}1,349 \\
251\end{array}$ & 2,88 & $\begin{array}{c}0,263 \\
871\end{array}$ \\
\hline 3,000 & $\begin{array}{c}1,069 \\
368\end{array}$ & 2,900 & $\begin{array}{c}1,336 \\
294\end{array}$ & 2,89 & $\begin{array}{c}0,263 \\
313\end{array}$ \\
\hline 3,010 & $\begin{array}{c}1,069 \\
181\end{array}$ & 2,910 & $\begin{array}{c}1,335 \\
919\end{array}$ & 2,90 & $\begin{array}{c}0,262 \\
876\end{array}$ \\
\hline 3,020 & $\begin{array}{c}1,069 \\
089\end{array}$ & 2,920 & $\begin{array}{c}1,335 \\
680\end{array}$ & 2,91 & $\begin{array}{c}0,262 \\
554\end{array}$ \\
\hline 3,025 & $\begin{array}{c}1,069 \\
077\end{array}$ & 2,930 & $\begin{array}{c}1,335 \\
570\end{array}$ & 2,92 & $\begin{array}{c}0,262 \\
342\end{array}$ \\
\hline 3,030 & $\begin{array}{c}1,069 \\
086\end{array}$ & 2,935 & $\begin{array}{c}1,335 \\
561\end{array}$ & 2,93 & $\begin{array}{c}0,262 \\
235\end{array}$ \\
\hline 3,040 & $\begin{array}{c}1,069 \\
168\end{array}$ & 2,940 & $\begin{array}{c}1,335 \\
582\end{array}$ & 2,94 & $\begin{array}{c}0,262 \\
226\end{array}$ \\
\hline 3,050 & $\begin{array}{c}1,069 \\
331\end{array}$ & 2,950 & $\begin{array}{c}1,335 \\
710\end{array}$ & 2,95 & $\begin{array}{c}0,262 \\
311\end{array}$ \\
\hline 3,060 & $\begin{array}{c}1,069 \\
569\end{array}$ & 2,960 & $\begin{array}{c}1,335 \\
948\end{array}$ & 2,96 & $\begin{array}{c}0,262 \\
485\end{array}$ \\
\hline 3,070 & $\begin{array}{c}1,069 \\
879\end{array}$ & 3,000 & $\begin{array}{c}1,337 \\
886\end{array}$ & 2,97 & $\begin{array}{c}0,262 \\
743\end{array}$ \\
\hline 3,080 & $\begin{array}{c}1,070 \\
257\end{array}$ & 3,100 & $\begin{array}{c}1,347 \\
967\end{array}$ & 2,98 & $\begin{array}{c}0,263 \\
081\end{array}$ \\
\hline 3,090 & 1,070 & 3,200 & 1,362 & 2,99 & 0,263 \\
\hline
\end{tabular}




\begin{tabular}{lll}
\hline 699 & 603 & 495 \\
\hline
\end{tabular}

From the table shown, we see that the optimum bond lenght of hydrogen in water-ater system is $3,025 \AA$, in methanol-water is $2,935 \AA$ and in ethanol-water system is $2,940 \AA$. It means that the optimum distance between atom $\mathrm{H}$ and atom $\mathrm{O}$ of ethanol-water system was $2,94 \AA$. It doesn't mean that $2,94 \AA$ is an exact values. Its an optimum distance, when it bond more or less than $2,94 \AA$ it may unstable or even broken. If we draw those data to be a graph, its show as :
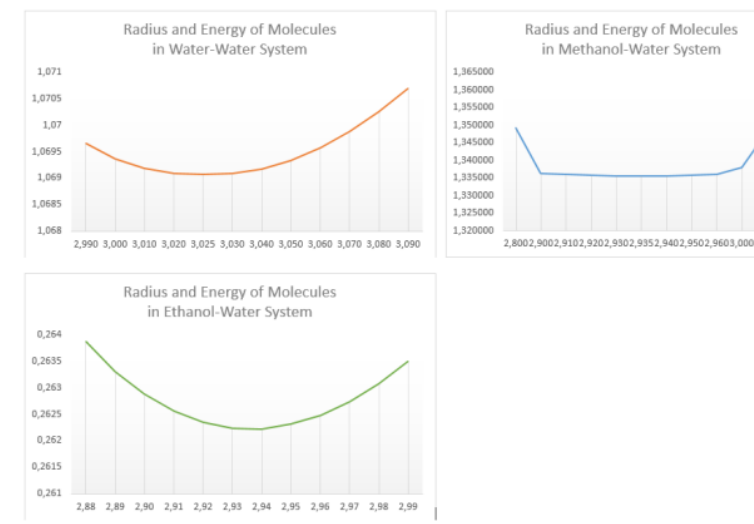

Figure 4. Graphic comparison of corellation between radius and molecular energy of hydrogen bond in water-water system, methanol-water system and ethanol-water system

In methanol-water system, the graph shows almost flat line. It means that along the line, hydrogend bond is in stable state, since the energy difference is $10^{-4} \mathrm{kkal} / \mathrm{mol}$. Different condition occurs in water-water and ethanol-water system, it has significant difference. The stable state of hydrogen bond is clearly seen.

When bond lenght and torsion were controlled and bond angle manipulated, it generates data as follows :

Table 2. The comparison of bonding angle and its energy in water-water system, methanol-water system and ethanol-water system

\begin{tabular}{cccccc}
\hline \multicolumn{2}{c}{$\begin{array}{c}\text { Water - } \\
\text { Water }\end{array}$} & $\begin{array}{c}\text { Methanol - } \\
\text { Water }\end{array}$ & \multicolumn{2}{c}{$\begin{array}{c}\text { Ethanol } \\
\text { - Water }\end{array}$} \\
\hline Bond & $\begin{array}{c}\text { Ener } \\
\text { Angle }\end{array}$ & $\begin{array}{c}\text { By } \\
\text { gyd }\end{array}$ & $\begin{array}{c}\text { Aner } \\
\text { Angle }\end{array}$ & $\begin{array}{c}\text { Bond } \\
\text { gngle }\end{array}$ & $\begin{array}{c}\text { Ener } \\
\text { gy }\end{array}$ \\
\hline $60,0^{0}$ & 1,08 & $120,0^{0}$ & 1,35 & $130,0^{0}$ & 0,11 \\
& 1129 & & 3039 & & 1877 \\
\hline $70,0^{0}$ & 1,06 & $130,0^{0}$ & 1,33 & $136,0^{0}$ & 0,06 \\
& 1373 & & 3752 & & 2685 \\
\hline $75,0^{0}$ & 1,05 & $140,0^{0}$ & 1,30 & $137,0^{0}$ & 0,06 \\
& 8431 & & 6441 & & 0771 \\
\hline $76,0^{0}$ & 1,05 & $145,0^{0}$ & 1,29 & $138,0^{0}$ & 0,04 \\
& 8193 & & 0564 & & 7492 \\
\hline $77,0^{0}$ & 1,05 & $150,0^{0}$ & 1,27 & $139,0^{0}$ & 0,04 \\
& 8048 & & 7442 & & 0711 \\
\hline $78,0^{0}$ & 1,05 & $151,0^{0}$ & 1,27 & $140,0^{0}$ & 0,03 \\
& 7989 & & 558 & & 4749 \\
\hline $\mathbf{7 9 , 0 ^ { 0 }}$ & $\mathbf{1 , 0 5}$ & $152,0^{0}$ & 1,27 & $141,0^{0}$ & 0,02 \\
& $\mathbf{8 0 0 5}$ & & 414 & & 9866 \\
\hline $80,0^{0}$ & 1,05 & $153,0^{0}$ & 1,27 & $142,0^{0}$ & 0,02 \\
& 8091 & & 322 & & 6376 \\
\hline $81,0^{0}$ & 1,05 & $\mathbf{1 5 4 , 0 ^ { 0 }}$ & $\mathbf{1 , 2 7}$ & $142,5^{0}$ & 0,02 \\
& 8239 & & $\mathbf{2 9 3 3}$ & & 5268 \\
\hline $82,0^{0}$ & 1,05 & $155,0^{0}$ & 1,27 & $143,0^{0}$ & 0,02 \\
& 8441 & & 3413 & & 4654 \\
\hline $83,0^{0}$ & 1,05 & $156,0^{0}$ & 1,27 & $\mathbf{1 4 3 , 5 ^ { 0 }}$ & $\mathbf{0 , 0 2}$ \\
& 8693 & & 4815 & & $\mathbf{4 5 9 2}$ \\
\hline $84,0^{0}$ & 1,05 & $160,0^{0}$ & 1,29 & $144,0^{0}$ & 0,02 \\
& 8987 & & 3713 & & 5147 \\
\hline $85,0^{0}$ & 1,05 & $170,0^{0}$ & 1,62 & $145,0^{0}$ & 0,02 \\
& 9319 & & 6007 & & 8389 \\
\hline $90,0^{0}$ & 1,06 & $180,0^{0}$ & 3,23 & $150,0^{0}$ & 0,11 \\
& 1384 & & 6965 & & 2664 \\
\hline & & & & & \\
\hline
\end{tabular}

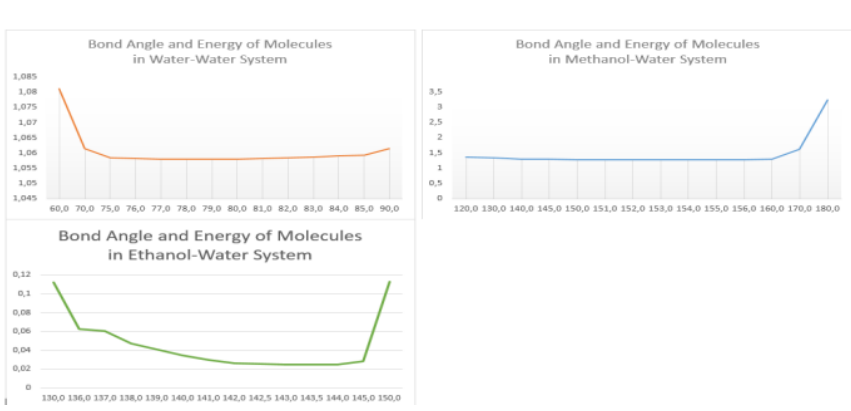

Figure 5. Graphic comparison of corellation between bond angle and molecular energy of hydrogen bond in water-water system, methanol-water system and ethanol-water system

We measure the angle between $\mathrm{H}--$ $\mathrm{OH}$ of related atom. Thus we measure $\mathrm{H}$ atom of water and $\mathrm{OH}$ from water, 
methanol, ethanol. As we see optimum bond angle in water-water systems is $79^{\circ}$, while in methanol-water is $154,0^{\circ}$, and in ethanol-water is $143,5^{\circ}$. Its differ because of surounding atom among hydrogen bond. In water-water system, there in no functional groups after atom $\mathrm{O}$, while methyl group in methanol system and ethyl group in ethanol-water sistem were exist. Besides the bond lenght and bond angle, bond torsion also influence the optimum form of hydrogen bond. Thus it necessary to be considered as measured below :

Table 3. The comparison of bonding torsion and its energy in water-water system, methanol-water system and ethanol-water system

\begin{tabular}{cccccc}
\hline \multicolumn{2}{c}{$\begin{array}{c}\text { Water - } \\
\text { Water }\end{array}$} & \multicolumn{2}{c}{$\begin{array}{c}\text { Methanol - } \\
\text { Water }\end{array}$} & $\begin{array}{c}\text { Ethanol - } \\
\text { Water }\end{array}$ \\
\hline Radiu & Energ & Radiu & Energ & Radiu & Energ \\
s (r) & $y$ & s (r) & y & s (r) & y \\
\hline $320^{0}$ & 1,059 & $253^{0}$ & 1,270 & $300^{0}$ & 0,023 \\
& 147 & & 996 & & 796 \\
\hline $330^{0}$ & 1,058 & $254^{0}$ & 1,270 & $310^{0}$ & 0,023 \\
& 668 & & 994 & & 662 \\
\hline $340^{0}$ & 1,058 & $255^{0}$ & 1,270 & $313^{0}$ & 0,023 \\
& 307 & & 992 & & 646 \\
\hline $350^{0}$ & 1,058 & $256^{0}$ & 1,270 & $\mathbf{3 1 4}^{\mathbf{0}}$ & $\mathbf{0 , 0 2 3}$ \\
& 082 & & 991 & & $\mathbf{6 4 2}$ \\
\hline $\mathbf{0}^{\mathbf{0}}$ & $\mathbf{1 , 0 5 8}$ & $\mathbf{2 5 7 ^ { 0 }}$ & $\mathbf{1 , 2 7 0}$ & $315^{0}$ & 0,023 \\
& $\mathbf{0 0 5}$ & & $\mathbf{9 9 0}$ & & 644 \\
\hline $10^{0}$ & 1,058 & $258^{0}$ & 1,270 & $316^{0}$ & 0,023 \\
& 082 & & 992 & & 645 \\
\hline $20^{0}$ & 1,058 & $259^{0}$ & 1,270 & $320^{0}$ & 0,023 \\
& 307 & & 994 & & 67 \\
\hline $30^{0}$ & 1,058 & $260^{0}$ & 1,270 & $330^{0}$ & 0,023 \\
& 668 & & 996 & & 887 \\
\hline
\end{tabular}

\section{CONCLUSION}

From the discussion we can conclude that the optimum form of hydrogen bond in water-water system is $3,025 \AA$ in lenght, $79^{\circ}$ in $\mathrm{HO}-\mathrm{H}$ angle and $0^{0}$ in bond torsion. Meanwhile in methanol-water system is 2,935 $\AA$ in lenght, $154^{\circ}$ in $\mathrm{HO}-\mathrm{H}$ angle and $257^{\circ}$ in bond torsion. For ethanol-water system the optimum form is $2,94 \AA$ in lenght, $143,5^{\circ}$ in $\mathrm{HO}-\mathrm{H}$ angle and $314^{\circ}$ in bond torsion.

\section{REFFERENCES}


Amrullah. (2016). Simulasi Dinamika Molekular. Yogyakarta.

Effendy. 2006. Teori VSEPR Kepolaran, dan Gaya Antarmolekul. Malang : Bayumedia Publishing.

Gutowska, I., Machoy, Z., \& Machaliński, B. (2005). The role of bivalent metals in hydroxyapatite structures as revealed by molecular modeling with the HyperChem software. Journal of Biomedical Materials Research - Part A, 75(4), 788-793.

https://doi.org/10.1002/jbm.a.30511

Jian Hua, Chen, Yu Cun, jin, Yingjie.Effects of hydrogen bond on melting potni of azole explosives. Jurnal of Molecular Structure. 2018

Kurniawan, Y dan Nur, M. 2005. Studi Penentuan Dinamika Proton Dalam Ikatan Hidrogen $\mathrm{H}_{2} \mathrm{O}$ Padatan Satu Dimensi, Berkala Fisika. 8 (3) : 107 $-117$.

Li Fabing, Men Zhiwei, Li Shuo, Wang Shenghan, Li Zhanlong, Sun Chenglin. Study of hydrogen bonding in ethanol-water ninary solutions by Raman spectroscopy. Jurnal Spectrochmica Acta part A: Molecular and Biomolecular Spectroscopy 189 (2018; 621 -624

Plummer, L. M. (1990). Molecular dynamics simulations and quantum mechanical studies of the hydrogen bond in water cluster systems*, 237(September 1989), 47-61.

Silberberg, M. S. (2015). Chemistry, The Molecular Nature of Matter and Change (7th ed.). New York: McGraw-Hill Education.

Stachowicz, A., \& Korchowiec, J. (2013). Bond Detectors for Molecular Dynamics Simulations, Part I: Hydrogen Bonds, 2261-269. https://doi.org/10.1002/jcc.23385 